\title{
Locating the social and political in secondary school literacy
}

$\mathrm{L}$ ike Ebenezer Scrooge's third ghost, we began this task as a discussion of what is to come in research on literacy in secondary schools. We started by considering what has gone before for the purpose of putting forth an argument about what could or should come next. In particular, we wanted to argue for a social and political view of literacy in secondary schools. However, as we began to make this argument, we became uncomfortable with the contradiction inherent in attempting to predict the future while simultaneously calling for attention to a shifting, uncertain notion of literacies in the present. Consequently, in this conversation we do not attempt to argue for a particular future, but rather, we suggest a number of possible futures for secondary literacy research. Although we do not give up on the importance of the social and political, we pose more questions than answers, and we view our conversation as part of a larger, ongoing dialogue among literacy scholars.

We consider this work a collaborative effort. Most of the talk that took place as we discussed the content of this piece is not represented here. What we share is edited, composed to a single outline with more commingling of our points of view than exists in most conversations. We each composed the sections attached to our respective names, but we helped each other with conceptualizations and wordings as we worked. What we do not share is how we pushed each other to seek new understandings and reveal those understandings in different ways.

Four critical literature reviews helped us to understand the larger historical context of our conversation.
These reviews connect our interest in secondary school literacy to the content area reading movement and point to cognitive psychology as the primary conceptual basis for our recent work. For instance, Moore, Readence, and Rickelman (1983) explained that early 20th-century insights merged with cognitive psychology in Herber's (1970) call for reading instruction across the secondary school curriculum in the United States. Alvermann and Moore (1991) called attention to the gap that eventually resulted from this merger, between experimental research into effective instructional strategies and actual secondary school practices. O'Brien, Stewart, and Moje (1995) argued that this gap developed because researchbased teaching strategies took on the shape of more traditional, nonreading-based instruction within the institution of the secondary school.

In a more recent review, Moore (1996) observed that research on secondary school literacy has moved of late toward a more context-sensitive focus on how and why teachers and students engage in particular literacyrelated activities. O'Brien et al. (1995) noted an analogous transition in our terminology, from concern for teaching reading per se to a broader definition of literacy as communicative competence in particular contexts. This broader definition of literacy serves as a departure point for our discussion of possible futures for secondary literacy research, teaching, and teacher education.

In the following sections, we explain why it is important to consider an even more shifting definition that locates the social and political in secondary school litera$\mathrm{cy}$, and we muse about the implications for secondary school literacy research. 


\section{Locating the social and political}

\section{Kathy}

One reason I think that attention to the social and political is important to our research conceptualizations is that it reminds us that when a teaching strategy, instructional material, or curriculum iteration works for most students, it is not working for others (Delpit, 1988; hooks, 1994). I began my career as a secondary school reading specialist who, thanks to suggestions like Durkin's (1978-1979), came to understand that testing comprehension was not the same as teaching it. Similarly, secondary content area literacy instructional strategies that were developed and tested during the 1970 s and 1980s made sense according to the tenets of the cognitive revolution (Herber, 1978; Readence, Bean, \& Baldwin, 1981; Vacca \& Vacca, 1984): Reading was a comprehension process of connecting new and known, and teachers could and should guide that process (Pearson \& Johnson, 1978; Rumelhart, 1980). More recently this work has included attention to issues of context and personal motivation (Dole, Duffy, Roehler, \& Pearson, 1991; Paris, Wasik, \& Turner, 1991; Pressley, Harris, \& Marks, 1992).

However, research to determine the effectiveness of these strategies (Alvermann \& Moore, 1991) is anchored in the premise that a treatment is more appropriate for our classroom use when it yields a result for most students that can be measured as greater than the result yielded by another treatment (cf. Greeno, 1997). On the other hand, Fine (1992) argued that some students are silenced by what seems to work for others because of the "institutionalized policies and practices which obscure the very social, economic, and therefore experiential conditions of students' daily lives, and which expel from written, oral, and nonverbal expression substantive and critical 'talk' about these conditions" (p. 157). If one of my students uses a discussion web (Alvermann, 1992) in her 10th-grade social studies class, I wonder whether everyone participates in the discussion. What if the student does not resonate with the teacher's declarative generalization, does not argue in the same way as other students, or does not value argument as a source of understanding? As a result of such questions, I have come to believe that teaching strategies said to work for most students may not be good enough. As Alvermann and Qian (1994) suggested, such strategies, while supported by research, may even serve to disenfranchise students.

\section{Elizabeth}

Several researchers in recent years have studied children's and adolescents' outside-of-school, everyday literacy practices, arguing that understanding these practices is critical to developing pedagogies that do not disenfranchise or marginalize students. Heath's (1983) landmark study, for example, illustrated the disjuncture between academic and social literacy practices among children of various social classes and ethnicities in the U.S. Carolina Piedmont. More recently, Heath and McLaughlin (1993) have pursued studies of youth organizations that operate outside of school, in an attempt to understand what makes these organizations appealing to young people and to suggest ideas for transforming schools in similar ways. Moll and Greenberg (1990) have studied the funds of knowledge that Latina/o children bring from home to school, funds of knowledge that typically are not understood, valued, or drawn on in academic literacy practices. Similarly, Camitta (1990) has studied the nonschool writing of urban adolescents, suggesting that they take hold of literacy in ways that are not recognized or valued in school. These out-of-school studies have recognized that to study children and adolescents in schools as students only is tantamount to suggesting that they have no life outside of school (Street, 1994). Furthermore, because schools are often sites of marginalization for particular students, to study some young people only in school is to know them only as marginalized beings.

\section{Kathy}

Related to this notion of marginalization, some explanations of the sociopolitical processes that drive our context-specific practices have noted the status-driven underpinnings of secondary schools. These explanations hint of teachers and students who are at the whim of the larger society, buffeted by the winds of class struggle, and destined to perpetuate existing societal inequities in our daily school life (Bowles \& Gintis, 1976; Everhardt, 1984; Grumet, 1988). Within this view, teachers serve as either conduits of students' oppression or liberators enacting empowerment pedagogies (Freire, 1968; Shor, 1980). Teaching the skills of literacy means providing the oppressed with the reading skills necessary for access to and disruption of the dominant cultural group. It also means moving from lecture-discussion, informationsharing pedagogy to something more active and student directed, yet with the disclaimer that the class structure may be so powerful that outcomes are inevitable despite pedagogical innovation. Not only is secondary teachers' disciplinary knowledge not valued as a significant basis for their expertise, but its sharing can be said to be a further basis for oppression. Short of revolution, I have found it difficult to be optimistic about finding pedagogical solutions within such a class-driven view. I've struggled with finding ways to think about human agency 
that are not based in individualistic assumptions but that also do not cast people-especially teachers and students—as cultural dupes.

Ellsworth (1989) and Gore (1993) are among the feminist poststructuralists who bring what I think is a more potential-filled way for researchers to consider the relation between people and their social worlds. They point out that the notion that teachers could presume to possess and distribute power to students belies our multiple positions and memberships, and our students' multiple positions and memberships, in a variety of social groups. For Ellsworth (1989) and others (Goldblatt \& Smith, 1995; Grant, 1996), the notion of teachers as omnipotent dictators of access to the class structure becomes especially questionable when we consider the conflict between the rhetoric of liberatory pedagogies and the reality that in many cases students do not feel empowered by teachers' invitations to speak.

Orner (1992) explained that power relations regulate our social interactions, but that our participation in multiple levels of social life places us in contradictory positions with which we struggle as we interact with others. Davies (1993a, 1993b) argued that, as we sort through our enactment of these positions, we have a measure of agency within the larger social realm: "Social patterns condone, support, approve, or make viable certain patterns of desire and outlaw or marginalize others" (Davies, 1993b, p. 12). That is, we make choices about what to say and do at particular points in time. Within such a view of being and knowing, the social shapes our words, but we are not powerless in the face of an immutable status structure. I think this view may be an important way to conceptualize research exploring secondary school literacy because it allows us to imagine teachers and students who act in ways that challenge social structures.

\section{Elizabeth}

As part of my research on out-of-school literacy practices, I asked José, a 13-year-old, gang-connected boy, why he thought that gangs were so much a part of adolescent life in today's schools. He responded that "Gangs have been around for a really long time-since the 60s and 70s-but they're different now-more widespread, more powerful. It's the 90s; everything's changing all the time."

"Everything's changing all the time." Whether he realizes it or not, José's explanation provides a postmodern rationale for rethinking literacy relative to the social order. Expanding information technologies continue to shrink our world, heightening our sense of diversity and our need to cross boundaries. Such changes create new demands for what people need to be able to do and think and be in our world. Because literacy and language are an enormous part of human doing and thinking and being (Gee, 1992; Street, 1994; Vygotsky, 1978), I believe that we need to think differently about what it means to teach people literacy. We need to move beyond definitions of literacy that focus solely on reading and writing "in page-bound, official, standard forms of the national language" (New London Group, 1996, p. 61) toward an acknowledgment that literate action requires the ability to navigate a multiplicity of discourses (Michaels \& O'Connor, 1990) or ways of reading, writing, talking, listening, and performing.

What does it mean to talk about discourses?

Discourses, as defined by Gee (1996), are

Ways of behaving, interacting, valuing, thinking, believing, speaking, and often reading and writing that are accepted as instantiations of particular roles (or "types of people") by specific groups of people, whether families of a certain sort, lawyers of a certain sort, bikers of a certain sort, business people of a certain sort, church members of a certain sort, African-Americans of a certain sort, women or men of a certain sort, and so on through a very long list. Discourses are ways of being "people like us." They are "ways of being in the world": they are "forms of life." They are, thus, always and everywhere social and products of social histories. (Gee, 1996, p. viii)

For me, that means that although I use the same basic code-or language-whether I'm at home, in my university classroom, in a junior high school classroom, or at a national research meeting, my discourse changes, sometimes in subtle ways, sometimes in drastic ways.

Recently, a graduate student transcribed some of my interviews with junior high school students. After her first transcribing session, she commented that I sounded like a completely different person on the tapes than I did in class. What she noticed was a difference in my discourse, not in my language, per se. She heard differences not only in the phrases I used when talking to these teenagers (e.g., "Hey, waz up?"), but also in my inflections, my pacing, and tone. Had she been able to see me during the interviews, she would also have noticed that I held my body differently when talking to the kids, and I certainly dressed differently for the interviews than I did for our graduate course.

These differences are called for by discourse and become aspects of the sense-making process in different interactions. Because literacy is integrally connected to discursive practices such as these, and because literacy can be conceived of as discourse, it seems important that secondary literacy researchers consider the many discourses secondary students and teachers navigate as they teach, learn, and use literacy. 
We can also talk about a discourse of schooling in which students, teachers, and administrators have different ways of "behaving, interacting, valuing, thinking, believing, speaking, and often reading and writing" (Gee, 1996, p. vii). The discursive practices called for by a discourse of schooling are subtle but important, especially to students. Hymes (1974) and Gumperz (1977) were some of the first sociolinguists to discuss the issue of communicative competence-the idea that being a student was not just about learning content knowledge and skills, but was also about learning how to communicate competently in school. A number of sociolinguistic studies have illustrated that schools operate according to a set of generally accepted—indeed, almost invisible—set of discursive practices, practices that reflect mainstream, middle-class conceptions of doing school (Tharpe \& Gallimore, 1988). As a result, many children are not communicatively competent in classrooms, often because of differences between their home discourses and school discourses (Cazden, 1988; Heath, 1983; Phillips, 1972).

An awareness of multiple discourses and communicative competence is especially important in thinking about secondary literacy, because secondary school students are confronted not only with the discourses of secondary schooling, but also with the discourses of the disciplines. These school and disciplinary discourses shape students' literacy practices. Students are expected to successfully weave together technical languages, themes, and concepts, as well as ways of talking, reading, writing, and being in several different disciplinary communities (Gee, 1996; Lemke, 1990). Adopting the literate practices of a discipline, whether consciously or unconsciously encouraged by teachers, is considered important to goals of scientific literacy (cf. Rutherford \& Ahlgren, 1990) or of thinking like a scientist, mathematician, or historian (Hicks, 1995-1996). Unfortunately, we don't know much about how students acquire these discursive practices and translate them into certain literacy practices. We also don't know much about why some students don't acquire these practices. Are the rules of such discourses-and, consequently, the literacy practices-so tacit, so invisible that some students are positioned as outsiders and not given access to the codes of the discipline or of the classroom?

\section{Kathy}

The notion of communicative competence adds another dimension to our attention to the social and political: It gives researchers a way to appreciate what teenagers bring with them when they walk through our schoolroom doors. Tied to the notion of our multiple and competing memberships in a variety of communities is the idea that the term literacy can be used in plural form, defined as "mastery of a [any] secondary discourse" (Gee, 1996, p. 143). That is, literacies exist when we learn discursive forms for communicative competence within communities other than those to which we were born. Gee suggested that one type of literacy is represented by our written-language competence, but that "we all have some [literacies] and fail to have others" (p. 143).

If we incorporate a view of multiple literacies into our research, then we can recognize that teachers' literacies provide some authority for orchestrating classroom activities, and students bring analogous, if different, literacies to their engagement in these activities. Teaching can be said to be a scaffolded apprenticeship to unacquired literacies (Gee, 1996), with teachers forming a pedagogy of shared authority (Oyler, 1996), inviting students to negotiate curricula from the grounding of their own discursive expertise. Teachers and students work to learn from one another, yielding a potential for new and helpful insights.

The concept of negotiated curriculum seems to shift us away from the idea that teachers should orchestrate students' reading and writing only in the name of predetermined outcomes of required curriculum. We can also question our tradition of encouraging teachers to use their content understandings to select literacy teaching strategies. O'Brien et al. (1995) suggested that the typical "secondary [school] curriculum is based on the assumption that knowledge can be objectified, verified, and disseminated via compartmentalized disciplines" ( $\mathrm{p}$. 448). Textbooks, reading, and other forms of instruction are used in ways to legitimate certain pieces of objectified knowledge while obviating others. This process of disseminating only some knowledge leaves the less skeptical of our students ignorant and the more skeptical disconnected. A more shifting, context-specific conceptualization may send students more powerful messages about the ways they can know, express their knowledge, and connect their knowledge across the contexts of their lives.

\section{Elizabeth}

Such a conceptualization is also important because in our rapidly changing and shrinking world we are encountering many different modes of sense making. If we think of literacy as ways of representing and communicating, then we have to acknowledge multiple modes or forms of representation (see Eisner, 1994; New London Group, 1996). In other words, literacy-or meaning making-can involve more than doing something with print; it can include making meaning through visual or oral representations, such as drawing, performing, or danc- 
ing. Literacy practices may revolve around electronic hypermedia where print, visual, and audio images merge to create a form of representation different from unidimensional and monomedial print matter. Or, literacy practice can involve using multiple media to interpret or transmediate (Siegel, 1995) understandings. An expanded definition of literacy doesn't require that the teaching of print literacy be discarded; it does suggest, however, that we need to think about changing our pedagogical and research approaches to embrace multiliteracies (New London Group, 1996).

This move beyond print literacies not only is called for by the changing world in which we live, but also may help secondary school teachers think about literacy and learning in alternative ways. When I teach secondary content area literacy methods at the university, I find that mathematics, music, dance, physical education, physics, and art majors find a shift from print literacy to multiliteracies quite compelling. When they see their content area specialties as ways of making meaning that can be read and written, they begin to think about the disciplines-and the tools students need to make sense of disciplinary knowledge-in different ways.

In addition to the awareness that we have entered an era in which people use multiple forms of literacy, recent theoretical arguments in literacy have highlighted the ideological nature of literacy and literate practices (Gee, 1993; Graff, 1987; Luke, 1995; Street, 1994; Volosinov, 1973). Street (1994) argued, "the meaning and uses of literacy practices are related to specific cultural contexts...these practices are always associated with relations of power and ideology" (p. 139). For example, in Conquergood's (1994) examination of gang discourse, material conditions surrounding gang life, and broader discourses about gangs, he illustrates how gangs are constructed as problems, despite the fact that the rhetoric of gang patriotism and loyalty is analogous to nationalistic rhetoric used to elicit support for institutionalized violence such as the recent Gulf War. Gang discourses and practices are constructed as deviant and destructive, whereas nationalistic discourses and practices (particularly when referenced to the United States) are upheld as necessary and productive.

Several of these theorists also argue that literacy practices are constitutive of identity (Gee, 1996), personhood (Street, 1994), or subjectivity (Luke, 1995). In other words, those people whose literacy practices are upheld as good, useful, and powerful may be positioned as good, useful, and powerful in social and cultural groups, whereas those whose literacy practices are not valued are positioned as lacking. In our increasingly multicultural and multiclass secondary schools, researchers should ask questions about what these different values mean for the education of all adolescents. We need also to recognize that students and teachers move in and out of different communities and different subject positions, and thus use multiple literacies in multiple ways.

\section{How might locating the social and political change our research?}

\section{Elizabeth}

If we reconceptualize what it means to be literate and to support students' development of new literacies, then we will need to ask new research questions. In their review of research on secondary literacy, Alvermann and Moore (1991) asserted that a great deal of research had been conducted on the development and implementation of literacy teaching and learning strategies for secondary school teachers and students. At the conclusion of their review, the authors called for an expanded research agenda that would build on studies like Bloome's (1987), Dillon's (1989), Hinchman's (1987), and Stewart's (1989) to investigate how and why teachers and students used literacy in classrooms and schools. As Readence, Kile, and Mallette (in press) have suggested, since that review was published a number of studies have been conducted on teachers' and students' decisions about and practices of literacy (e.g., Hinchman \& Zalewski, 1996; Moje, 1996; Myers, 1992; Sturtevant, 1996).

Six years after Alvermann and Moore, I find myself echoing a revised version of a call for expanded research focuses. Specifically, I think that as a group of researchers we need to expand our focus from teachers' beliefs, decisions, and practices to include other school participants' beliefs, decisions, and practices. In particular, as a secondary literacy community, we have focused our research efforts looking at academic literacy practices and have neglected to a large extent what Goffman (1961) called the "underlives" that develop within social groups (p. 305). In a recent piece on reconceptualizing adolescent literacies, Kathy (Hinchman, in press) argued that although a number of secondary literacy researchers (including Kathy and me) have studied students' practices, we have characterized students as a group, rather than studying them closely as individual students. We need to look more closely at particular students' literacy practices, find out what they think about school, about different content areas, and about how their outside-ofschool lives influence and merge with their in-school lives. An equally interesting question might be to ask how students and teachers weave such different and competing literacies together. 


\section{Kathy}

I also think we can improve the ways in which our research represents adolescents as multidimensional human beings who bring a variety of unique insights into our classrooms-instead of as aggregated representatives of a misguidedly singular student perspective. I am interested in exploring the ways particular adolescents enact their various literacies in classrooms, and in placing their views closer to the foreground of my explanationsinstead of favoring my own views or those of the teachers who host my classroom visits (Hinchman, in press). I think it is especially important to consider how the ways we represent students in our research can be helpful to our pedagogies (Obidah, in press). Secondary teachers struggle daily with knowing large numbers of students, using their insights as the basis for their ongoing classroom negotiations, but cutting compromises in the ways they attend to some as they address the needs of others. If we learn to represent particular adolescents more respectfully in our research, the processes or products of our efforts may help teachers to construct their own richer understandings of the teenagers in their classrooms.

It may also be helpful to gain insight into adolescents' particular text engagements in ways more specific than our previous aggregated representations could allow. It will be interesting to understand more about the ways these engagements seem shaped by individuals' multiple social memberships, including those tied to issues of gender, race, and class. Work by such scholars as Christian-Smith (1993), Davies (1993a, 1993b), Flynn and Schweickart (1986), Gilbert (1993), and others presents us with some models for considering the way such ties shape our literate engagements, and the ways our literate engagements, in turn, shape our enactments of our social ties.

As one whose job includes making pedagogical recommendations to new teachers, I am also concerned with developing research to explore how the schematheoretic instructional strategies of the last two decades work in classrooms of negotiated curriculum. Especially important are those studies (Dillon \& Moje, in press; Floriani, 1993; Prentiss, in press) that ask questions about the nature of literacy processes and texts within such contexts. Who chooses the texts to be read and why? How are students included in selected readings or not? Whose interpretations of texts are most valued and why? What intertextual connections are made, whose interpretations are represented, and how are the interpretations woven together (Bloome \& Egan-Robertson, 1993; Hartman, 1992)? What happens when teachers ask particular students to engage in activities meant to extend text understandings according to what the teacher sees as important, and how does this guidance change when the teacher is willing to negotiate the idea of importance (Dillon, O'Brien, Wellinski, Springs, \& Stith, 1996; O'Brien, in press)? I am inclined to think that some disciplines may lend themselves more easily to student and teacher negotiation of curriculum (Fecho, in press), but other disciplines' traditionally content-heavy curricula may require more extensive revisiting for effective negotiations to take place.

\section{Elizabeth}

I am interested in studying similar questions about pedagogy. My questions focus on other pedagogies that have gained-or regained-prominence in recent years. Specifically, I am interested in expressivist, child-centered, or progressivist pedagogies used to teach literacy. Although often suggested as a way to decenter teacher authority and to inspire students' self-expression and self-exploration, expressive and progressive pedagogies such as the readers' and writers' workshop (cf. Atwell, 1987; Elbow, 1973) and progressive, child-centered pedagogies may actually privilege the literacy practices of white, middle-class students and maintain the status quo (cf. Berlin, 1987; Lensmire, 1994). Usher and Edwards (1994) suggested that child-centered, autonomy-driven pedagogies are actually insidious means of controlling students because they place all responsibility for students' success or failure on the individual and fail to acknowledge social and cultural context. Thus, students whose experiences are valued in the culture of power (Delpit, 1988), and who are skilled in its practices, are rewarded and validated. Students whose experiences are not valued continue to be alienated from and marginalized by these school literacies.

To illustrate how children from nonmainstream groups sense that their cultural experiences are not valued even in child-centered, expressivist classrooms, Willis (1995) documented her son's attempts to fit into mainstream conceptions of writing by making up stories of his experience to write about in the writers' workshop. She argued that these pedagogies do little to value or acknowledge diverse social and cultural experiences.

Equally important is the argument that the exploration of individual experience does not challenge students to critically examine their experiences and texts in relation to larger social and cultural texts (Lensmire, 1994). Specifically, since these approaches are geared to the exploration of personal experience, they preclude reading, writing, thinking, and questioning that depend upon larger group experiences. Students are not asked or encouraged to think beyond their experiences or to locate themselves in a larger social and political world. Thus, expressive and progressive pedagogies can become colorblind and genderblind and may fail to pro- 
vide the tools for understanding how individuals can be marginalized or oppressed (Moje \& Thompson, 1996).

I'd like to suggest that expressivist, progressivist, and child-centered pedagogies need to be carefully studied, and perhaps reconceptualized and restructured to encourage students to explore social and political implications in the texts they use and create (cf. Lensmire, 1994). We do need to draw on students' experiences, but we must also walk with students beyond the reaches of our worlds, help them learn to talk back to texts of their experience (hooks, 1989), and encourage them to challenge assumptions tacit in the discourses and practices around them. Kamberelis and de la Luna (1996), Lensmire (1994), and McCarthey (1996) have raised such questions about expressivist and progressive practices at the elementary school level; Alvermann (1996), Finders (1996), Oates (1996), and my colleague Audrey Thompson and I (Moje \& Thompson, 1996) have examined these questions at the secondary level and offer some possible research directions in English classrooms. In addition, we should explore how child-centered, expressivist, or progressive pedagogies may take shape in other disciplines. Are students pushed beyond their own experiences? Is the authority of the teacher actually decentered? What is gained or lost in these approaches?

\section{Kathy}

I also value the idea of studying literate enactments outside of school. For instance, because of their superficial and often one-sided coverage of too much content, textbooks have long been critiqued as a primary source of information in secondary schools (Alvermann \& Commeyras, 1994). Social conceptualizations of literacy suggest that our definitions of text should be dynamic ones, attending to all the technologies and communicative mechanisms that are available to us (Flood \& Lapp, 1995). I think it could be really interesting to enter the settings where people engage in discipline-specific work to learn about the kinds of texts they find most useful in this work. The texts that appeal to us in leisure are also important to understand. We who live academic lives, including researchers and teachers, need to learn about the texts that are important to those who are not regularly involved in academic contexts, to explore the interpretations desired in particular settings, and to consider whether and how such transactions may be foreshadowed in school. We also need to be concerned with matters of who has access to which texts, and how this access affects ability to participate in particular discussions.

In the manner that Taylor and Dorsey-Gaines (1988) considered the family literacy of the socioeconomically disadvantaged, I also think it would be interesting to explore what is meant by a literate life for those who would appear to be more or less privileged members of our society. However, I think that the story literacy researchers tell may be very different from the one that is told by either teachers, with their differing notions of disciplinary expertise, or by teenagers, most attuned to the current and yet-to-come ways of being in the world. Although some have suggested that it would be most powerful if these individuals would author texts about their literacies, we need to question our motivation for asking others to create texts that serve our needs as outsiders to their worlds (Orner, 1992). What would such texts do for their authors?

Rather than asking teachers and teenagers to author their own texts, it may be important to invite them to collaborate in the development of our classroom research. Those who are concerned with representing emic perspectives (Oldfather, 1995) and with conducting teacher research (Allen \& Shockley, 1996; Santa Barbara Discourse Group, 1994) will also help us to gain insights into individuals' contextualized points of view. Collaborative research, representing inside- and outsidethe-classroom views of what goes on in particular settings daily (Cochran-Smith \& Lytle, 1993) may also continue to be helpful for negotiating the combination of reflection and action that can help us to see life in classrooms in new ways.

Our research may be even more productive when we figure out a way to invite our secondary school students to the collaborative table. Our ability to understand teenagers' insights would be aided if they could be compelled to share their own points of view, or more, to explore the perspectives of their teachers, of researchers, and of others with insights about how the world works, about the application of literacy processes in the out-ofschool world, and about the role of disciplinary expertise. In a classroom of shared authority, adolescents should be prepared to talk with and challenge their teachers about issues of gender, race, class, and curricula. Teachers should do the same, and researchers can explore teachers' and students' insights as they engage in such negotiations.

\section{Elizabeth}

Like Kathy, I believe that we must start to look more closely at and listen more carefully to adolescents' literacy practices. My particular interests revolve around how students use literacies other than those privileged in schools (a focus on understanding the multiple literacies that students use to make sense of their lives and of the world) and in how those different forms of literacy are valued or devalued in school and society. Whose literacy practices are currently valued in schools? Why? How do these literacy practices support particular conceptions of 
knowledge, such as truth and reason versus falsehood and folly (cf. Foucault, 1972)? Whose interests are served in promoting these conceptions of knowledge? How are academic literacy practices complicit with hegemonic practice, that is, how do these practices allow for the domination-albeit nonviolent-of some groups?

If we choose to broaden our research focuses, then we will likely find ourselves in new research venues. We cannot remain inside classrooms, for example, if we hope to learn more about students' social literacies. We'll find ourselves in hallways, restaurants, malls, community centers, and the streets. If we want to challenge and change the structures that support oppressive social and school practices, we will need to engage in action research practices that require our participation. Schools and classrooms-where many of us currently conduct our research-are important sites for understanding literacy. It seems, however, that at the secondary level we need to follow the lead of a number of literacy scholars and begin to document how and why literacy is used in other sites, such as teachers' and students' homes and communities (e.g., Heath \& McLaughlin, 1993; Moll \& Greenberg, 1990), hangouts and social groups (e.g., Finders, 1996; Hartman \& Shoop, 1997), workplaces and professions (e.g., Ackerman, 1995, 1996), and cyberspace sites such as the Internet (Bekins, 1996).

I am currently studying how adolescents use literacy in unsanctioned, unorganized adolescent peer groups (also known as gangs) as a way of understanding why and how these adolescents use literacy in their English and other content area classrooms. Until recently, my research has focused on how and why literacy was used in disciplinary settings, often with successful students. Even among those successful students I found a number of different literacies and subjectivities being performed in the classroom. But when I began to study among unsuccessful or marginalized students-those students often considered by school personnel to be at risk of failure, problem students, or low achievers-I began to appreciate the awesome task that many of these students faced in negotiating or navigating distinctly different discourses of home, community, street, and school.

Although all students must negotiate a number of different discourses, those students whose outside-ofschool experiences are similar to their inside-of-school experiences encounter a somewhat simpler task. I believe that the secondary literacy community needs to begin a more intensive study of students who aren't particularly successful in school. Rather than trying to fix them by only providing strategies for learning mainstream literacies, we need to understand how they use literacy productively in their lives and communities and use this understanding to help them gain whatever access to mainstream literacies that the students desire.

We need to find out not only what people do with literacy in various sites of learning, but also how they weave their home, community, church, and workplace literacies together with academic literacies. I find that I learn as much about adolescents' literacy practices while sitting in their living rooms surrounded by parents, siblings, and cousins, as I do when sitting in an English or chemistry classroom. This seems to be an exciting and productive research possibility that might help us understand ways to change our approaches to teaching academic literacies so that we might reach more students. We need to take a careful look at the purpose of the academic literacies we now promote; perhaps thinking about what these literacies actually do for people outside of school is a better goal than trying to find more and better strategies for teaching them. In suggesting this shift in our research agenda, I do not advocate privileging nonacademic literacies over academic ones, but I do suggest that we need to value them equally.

This shift into different sites of learning might be important not only for our research, but also for literacy teacher education programs. Zebroski (1990) asked his preservice composition teachers to conduct and write community ethnographies, believing that teachers cannot teach students if they do not understand their students' lives and experiences. Perhaps we need to do something similar, both in our research and teacher education programs.

\section{Kathy}

I was struck during my rereading of our literature at how parochial our concerns have been in more than one respect. I think we have begun to add depth and breadth to the ways we think about literacies and texts as we ask questions about the meshing of sensibilities and ideological underpinnings. However, we remain narrow in another sense, considering only the notions of literacies held by those in the United States. This seems ironic at a time when the networks by which we organize our information have become increasingly global in orientation. As Street (1994) suggested, I find myself wanting to hear about comparisons of insights across cultures with varying status hierarchies and, thus, ways of constructing and representing meaning. How do adolescents participate in schooling across the world, and how does their participation differ according to gender, race, and class? What can we learn from cross-cultural comparisons that will allow us to expand our insights regarding this very social notion of communicative competence? 
One more productive site for our inquiry may well be a look inward by members of the research community who are most concerned with literacy development in secondary schools. Such critical praxis has been recommended by a wide range of scholars who see it as a step toward understanding better our criticisms of others (e.g., Harding, 1987; Lemke, 1995). I have found such self-exploration useful for querying my own attention to issues of representation, point of view, and the influence of my own beliefs on how I see classroom life. As a research agenda, such self-query might be less helpful because of its idiosyncrasies, but when we connect our own work with other studies, we begin to understand how particular theoretical paradigms frame our ways of seeing.

\section{Concerns and cautions for a social and political view of literacy}

\section{Kathy}

Elizabeth and I talked a lot about how much fun we were having as we constructed this conversation, partly because we pushed each other, and partly because we connected these concerns to our shared background as secondary teachers with both successful and unsuccessful experiences: There is nothing more sobering than watching teenagers choose to exit your classroom, your school, because they find nothing in it that suits their interests or plans. We also know that our research often does not have the impact we intend, and that some will view our conversation as a precious endeavor as a result. For example, some practitioners have a powerful sense already of particular students' sensibilities, and they close their doors and practice a pedagogy that reflects such insight, spans paradigms, and is engaging and successful by anyone's measure.

At the same time, I fear that our agenda shifts have unanticipated consequences. I worry that our transition to promoting instruction integrated into subject area teaching meant that we gave up searching for the most appropriate pedagogies for less skilled adolescent readers. I wonder whether our present use of the word liter$a c y$ instead of reading and writing opens us up to so many interpretations that we come to neglect teenagers' very real need for print-related access to dominant information sources. I don't intend to suggest a focus on students' strengths and interests that will cause us to abdicate a very necessary search for literacy skills pertinent to disciplinary expertise. After all, I believe that the ability to navigate disciplinary discourses is critical to students' communicative competence.

Elizabeth and I belong to a listserv on secondary school literacy, managed by Elizabeth Sturtevant at
George Mason University (SECONDARY-

LITERACY@gmu.edu), whose recent discussions echo my fears: Talk has been concerned with the lessened role of the secondary reading specialist, the decline in the number of states requiring a content literacy course for certification, the move of federal funding priorities to an emphasis on beginning reading instruction, and the competing implications of recently developed standards on literacy-related instruction.

I wonder what the consequences will be with a shift in attention to the social and political. What will such research look like? What do we lose with our attention to a pedagogy of the particular? I especially wonder what an emphasis on the contextual does for teenagers who enter our secondary schools as less successful students according to traditional standards. Does such talk leave some students at a disadvantage because they lack the print-related skills needed to have access to the negotiations? Will the students who now have the most access to the privileges of schooling as their birthright end up continuing to have the most access because their heritage includes the transmission of needed skills?

\section{Elizabeth}

Although I believe that attention to the social and political in secondary literacy is critical to the development of pedagogies that benefit all students, I am also acutely aware of the potential pitfalls of the expanded definitions and research focuses that we have discussed in this piece. First, a definition of literacy that moves beyond print literacy toward multiple forms of representation may be viewed as shifting attention from very real concerns about how to teach adolescents to read and write critically. Even though it can be argued that this expanded definition may be exactly what we need to improve the teaching of critical literacy skills for all students, the adoption of a broad stance can make it difficult to make specific, concrete recommendations.

Moreover, if we focus on students' perspectives and on their social and out-of-school literacies, will secondary literacy researchers be faced with the question: What does this mean for teachers on Monday morning? And how will we answer that question? How do we take findings about students' shifting subjectivities, negotiated literacies, and the ideological nature of literacy practice in secondary schools and make recommendations for educational practice? As Kathy wonders, what will our findings mean for students?

Similarly, if we critique pedagogical approaches, will we be viewed as pessimistic and hopeless? Will we force teachers and researchers into a kind of "existential nausea" (Murphy \& Smith, 1991, p. 51) in which every person's problem or literacy is legitimate, and no move 
is right, fair, or ethical because everything can be problematized and because progress is a myth? How do we acknowledge systemic issues and the desire for positive and lasting change in a world where change yields unpredictable outcomes and little is stable? How do we decide whose agendas take precedence and for whom literacy research should be conducted?

These are frustrating questions, but I think they point to a need to focus our work in local and particular contexts rather than trying to generalize to large groups of students or teachers, to be more willing to view findings as tentative and open to question, to problematize our research and teaching decisions, and to be aware that each solution we offer from research can result in unintended-and often negative-consequences.

Nevertheless, we need to remember that each of us has a responsibility to action. If we expand our definitions of literacy and our research focuses, then we will need to think carefully about how to talk and write about our work in ways that open up possibility, rather than obfuscate, confuse, and immobilize.

\section{Extending the conversation}

We returned to the Moore, Readence, and Rickelman (1983) review to look at their sense of the recurring issues in secondary content area reading instruction and to see if we somehow were attending to or should attend to the same issues. Their list included the debate about the most appropriate locations for instruction in needed skills, the argument that students need support as they learn to meet the reading demands of various subjects, the pursuit of ways to teach students to study with greater success, the search for instructional materials suited to disciplinary study and students' abilities, and the issue of when to begin subject-specific reading instruction. Overall, their synopsis reported that the bulk of the research attention over this century has been to help students to read to meet existing academic requirements. We allude to analogous issues of students' needs, pedagogy, disciplinary knowledge, and sources of texts and technologies. However, we embed these issues within a conception of literacies as forms of social and political practice. We see a number of possible futures for research related to secondary school literacy, and we hope this piece opens a space for continued conversation.

\section{REFERENCES}

ACKERMAN, J.M. (1995, October). The engendering of disciplinary knowledge. Paper presented to the National Academy of Education Spencer Fellow Presentations, Cambridge, MA.

ACKERMAN, J.M. (1996, April). From ideology to dialogue:
Expertise on the fault line. Paper presented at the annual meeting of the American Educational Research Association, New York.

ALLEN, J., \& SHOCKLEY, B. (1996). Conversations: Composing a research dialogue: University and school research communities encountering a cultural shift. Reading Research Quarterly, 31, 220-228.

ALVERMANN, D.E. (1992). The discussion web: A graphic aid for learning across the curriculum. The Reading Teacher, 45, 92-99.

ALVERMANN, D.E. (1996). Peer-led discussions: Whose interests are served? Journal of Adolescent \& Adult Literacy, 39, 282-289.

ALVERMANN, D.E., \& COMMEYRAS, M. (1994). Inviting multiple perspectives: Creating opportunities for student talk about gender inequalities in texts. Journal of Reading, 37, 566-571.

ALVERMANN, D.E., \& MOORE, D.W. (1991). Secondary school reading. In R. Barr, M. Kamil, P. Mosenthal, \& P.D. Pearson (Eds.), Handbook of reading research (vol. 2, pp. 951-983). White Plains, NY: Longman.

ALVERMANN, D.E., \& QIAN, G. (1994). Perspectives on secondary school reading: Implications for instruction. Reading and Writing Quarterly, 10, 21-38.

ATWELL, N. (1987). In the middle: Writing, reading, and learning with adolescents. Portsmouth, NH: Heinemann.

BEKINS, L.K. (1996, December). Text and context: Using sociocultural theory to examine the activity surrounding the use of electronic literacy. Paper presented at the annual meeting of the National Reading Conference, Charleston, SC.

BERLIN, J. (1987). Rhetoric and reality: Writing instruction in American colleges, 1900-1985. Urbana, IL: National Council of Teachers of English.

BLOOME, D. (1987). Reading as a social process in a middle school classroom. In D. Bloome (Ed.), Literacy and schooling (pp. 124-149). Norwood, NJ: Ablex.

BLOOME, D., \& EGAN-ROBERTSON, A. (1993). The social construction of intertextuality in classroom reading and writing. Reading Research Quarterly, 28, 305-333.

BOWLES, S., \& GINTIS, H.L. (1976). Schooling in capitalist America. New York: Basic Books.

CAMITTA, M. (1990). Adolescent vernacular writing: Literacy reconsidered. In A.A. Lunsford, H. Moglen, \& J. Slevin (Eds.), The right to literacy (pp. 262-268). New York: Modern Language Association.

CAZDEN, C. (1988). Classroom discourse: The language of teaching and learning. Portsmouth, NH: Heinemann.

CHRISTIAN-SMITH, L. (Ed.). (1993). Texts of desire: Essays on fiction, femininity, and schooling. Washington, DC: Falmer.

COCHRAN-SMITH, M., \& LYTLE, S.L. (1993). Inside outside: Teacher research and knowledge. New York: Teachers College Press.

CONQUERGOOD, D. (1994). For the nation: How street gangs problematize patriotism. In H.W. Simons \& M. Billig (Eds.), After postmodernism: Reconstructing ideology critique (pp. 200-221). Newbury Park, CA: Sage.

DAVIES, B. (1993a). Beyond dualism and towards multiple subjectivities. In L. Christian-Smith (Ed.), Texts of desire: Essays on fiction, femininity, and schooling (pp.145-173). London: Falmer.

DAVIES, B. (1993b). Shards of glass: Children reading and writing beyond gendered identities. Cresskill, NJ: Hampton Press.

DELPIT, L. (1988). The silenced dialogue: Power and pedagogy in educating other people's children. Harvard Educational Review, 58, 280-298.

DILLON, D. (1989). Showing them that I want them to learn and that I care about who they are: A microethnography of the social organization of a secondary low-track English classroom. American Educational Research Journal, 26, 227-259.

DILLON, D., \& MOJE, E. (in press). Listening to the talk of adolescent girls: Lessons about literacy, school, and life. In D.E. Alvermann, K.A. Hinchman, D.W. Moore, S. Phelps, \& D. Waff (Eds.), 
Reconceptualizing literacies in adolescents' lives. New York: Erlbaum. DILLON, D., O'BRIEN, D., WELLINSKI, S.A., SPRINGS, R., \& STITH, D. (1996). Engaging "at risk" high school students: The creation of an innovative program. In D.J. Leu, C.K. Kinzer, \& K.A. Hinchman (Eds.), Literacies for the 21st centuries: Research and practice. 45th yearbook of the National Reading Conference (pp. 232-244). Chicago: National Reading Conference.

DOLE, J.A., DUFFY, G.G., ROEHLER, L.R., \& PEARSON, P.D. (1991). Moving from the old to the new: Research on reading comprehension instruction. Review of Educational Research, 61, 239-264.

DURKIN, D. (1978-1979). What classroom observations reveal about reading comprehension instruction. Reading Research Quarterly, 15, 481-533.

EISNER, E. (1994). Cognition and curriculum reconsidered (2nd ed.). New York: Teachers College Press.

ELBOW, P. (1973). Writing without teachers. New York: Oxford University Press.

ELLSWORTH, E. (1989). Why doesn't this feel empowering? Working through the repressive myths of critical pedagogy. Harvard Education Review, 59, 297-324.

EVERHARDT, R. (1984). Reading, writing, and resistance: Adolescence and labour in a junior high school. Boston: Routledge \& Kegan Paul.

FECHO, R. (in press). Crossing boundaries of race in a critical literacy classroom. In D.E. Alvermann, K.A. Hinchman, D.W. Moore, S. Phelps, \& D. Waff (Eds.), Reconceptualizing literacies in adolescents' lives. New York: Erlbaum.

FINDERS, M. (1996). "Just girls": Literacy and allegiance in junior high school. Written Communication, 13, 93-129.

FINE, M. (1992). Disruptive voices: The possibilities of feminist research. Ann Arbor, MI: University of Michigan Press.

FLOOD, J., \& LAPP, D. (1995). Broadening the lens: Toward an expanded conceptualization of literacy. In K.A. Hinchman, D.J. Leu, \& C.K. Kinzer (Eds.), Perspectives on literacy research and practice. 44th yearbook of the National Reading Conference (pp. 1-16). Chicago: National Reading Conference.

FLORIANI, A. (1993). Negotiating what counts: Roles and relationships, texts and contexts, content and meaning. Linguistics and Education, 5, 241-273.

FLYNN, E., \& SCHWEICKART, P.P. (Eds.). (1986). Gender and reading: Essays on readers, texts, and contexts. Baltimore: Johns Hopkins University Press.

FOUCAULT, M. (1972). The archaeology of knowledge. New York: Pantheon.

FREIRE, P. (1968). Pedagogy of the oppressed. New York: Seabury Press.

GEE, J.P. (1992). The social mind: Language, ideology, and social practice. New York: Bergin \& Harvey.

GEE, J.P. (1993). Postmodernism and literacies. In C. Lankshear \& P.L. McLaren (Eds.), Critical literacy: Politics, praxis, and the postmodern (pp. 271-295). Albany, NY: State University of New York Press.

GEE, J.P. (1996). Social linguistics and literacies: Ideology in the discourses (2nd ed.). Bristol, PA: Taylor \& Francis.

GILBERT, P. (1993). Narrative as gendered social practice: In search of different story lines for language research. Linguistics and Education, 5, 211-218.

GOFFMAN, E. (1961). Asylums: Essays on the social situation of mental patients and other inmates. Chicago: Aldine.

GOLDBLATT, E., \& SMITH, M.W. (1995). Alone with each other: Conceptions of discussion in one college classroom community.

Linguistics and Education, 7, 327-348.

GORE, J. (1993). The struggle for pedagogies. New York: Routledge.

GRAFF, H. (1987). The legacies of literacy: Continuities and contra- dictions in western culture and society. Bloomington: Indiana University Press.

GRANT, R. (1996). The ethics of talk: Classroom conversation and democratic politics. Teachers College Record, 97, 470-482.

GREENO, J.G. (1997). On claims that answer the wrong questions. Educational Researcher, 26, 5-17.

GRUMET, M. (1988). Bitter milk: Women and teaching. Amherst, MA: University of Massachusetts Press.

GUMPERZ, J.J. (1977). Conversational influence and classroom performance. In J. Green \& C. Wallat (Eds.), Ethnography and language in school settings (pp. 3-23). Norwood, NJ: Ablex.

HARDING, S. (1987). Feminism and methodology. Bloomington, IN: Indiana University Press.

HARTMAN, D.K. (1992). Intertextuality and reading: The text, the reader, the author, and the context. Linguistics and Education, 4, 296-311.

HARTMAN, D.K., \& SHOOP, K.J. (1997). "Content-area literacy": Cases in the everyday content, texts, and practices of African American male adolescents. Unpublished manuscript.

HEATH, S.B. (1983). Ways with words: Language, life, and work in communities and classrooms. New York: Cambridge University Press.

HEATH, S.B., \& MCLAUGHLIN, M.W. (Eds.). (1993). Identity and inner city youth: Beyond ethnicity and gender. New York: Teachers College Press.

HERBER, H.L. (1970). Teaching reading in content areas. Englewood Cliffs, NJ: Prentice Hall.

HERBER, H.L. (1978). Teaching reading in content areas (2nd ed.). Englewood Cliffs, NJ: Prentice Hall.

HICKS, D. (1995-1996). Discourse, learning, and teaching. In M.W. Apple (Ed.), Review of research in education (vol. 21, pp. 49-95).

Washington, DC: American Educational Research Association.

HINCHMAN, K.A. (1987). The textbook and three content-area teachers. Reading Research and Instruction, 26, 247-263.

HINCHMAN, K.A. (in press). Reconstructing our understandings of adolescents' participation in classroom literacy events: Learning to look through other eyes. In D.E. Alvermann, K.A. Hinchman, D.W. Moore, S. Phelps, \& D. Waff (Eds.), Reconceptualizing literacies in adolescents' lives. New York: Erlbaum.

HINCHMAN, K.A., \& ZALEWSKI, P. (1996). Reading for success in a tenth-grade global-studies class: A qualitative study. Journal of Literacy Research, 28, 91-106.

HOOKS, B. (1989). Talking back: Thinking feminist, thinking black. Boston: South End Press.

HOOKS, B. (1994). Teaching to transgress: Education as the practice of freedom. New York: Routledge.

HYMES, D. (1974). Foundations of sociolinguistics. Philadelphia: University of Pennsylvania Press.

KAMBERELIS, G., \& DE LA LUNA, L.C. (1996). Constructing multiculturally relevant pedagogy: Signifying on the basal. In D. Leu, C. Kinzer, \& K.A. Hinchman (Eds.), Literacies for the 21st century: Research and practice. 45th yearbook of the National Reading Conference (pp. 329-344). Chicago: National Reading Conference.

LEMKE, J.L. (1990). Talking science. Norwood, NJ: Ablex.

LEMKE, J.L. (1995). Textual politics: Discourse and social dynamics. Bristol, PA: Taylor \& Francis.

LENSMIRE, T. (1994). When children write: Critical revisions of the writing process. New York: Teachers College Press.

LUKE, A. (1995). Text and discourse in education: An introduction to critical discourse analysis. In M.W. Apple (Ed.), Review of research in education (vol. 21, pp. 3-48). Washington, DC: American Educational Research Association.

MCCARTHEY, S. (1996, December). Learning the "qualities of good writing": Literacy practices in elementary schools. Paper presented at the 
annual meeting of the National Reading Conference, Charleston, SC.

MICHAELS, S., \& O'CONNOR, M.C. (1990). Literacy as reasoning within multiple discourses: Implications for policy and educational reform. Paper presented at the Council of Chief State School Officer Summer Institute, Newton, MA.

MOJE, E.B (1996). I teach students, not subjects: Understanding teacher-student relationships as contexts for literacy practices in a high school content classroom. Reading Research Quarterly, 31, 172-195.

MOJE, E.B., \& THOMPSON, A. (1996, September). Sociocultural practice and learning to write in school: Exploring the communicative and transformative potential of gang literacies. Paper presented at the Second Conference for Sociocultural Research, Vygotsky/Piaget Centennial, Geneva, Switzerland.

MOLL, L.C., \& GREENBERG, J. (1990). Creating zones of possibilities: Combining social contexts for instruction. In L.C. Moll (Ed.), Vygotsky and education (pp. 319-348). New York: Cambridge University Press.

MOORE, D.W. (1996). Contexts for literacy in secondary schools. In D.J. Leu, C.K. Kinzer, \& K.A. Hinchman (Eds.), Literacies for the 21st century: Research and practice. 45th yearbook of the National Reading Conference (pp. 15-46). Chicago: National Reading Conference.

MOORE, D.W., READENCE, J.E., \& RICKELMAN, R.J. (1983). An historical exploration of content area reading instruction. Reading Research Quarterly, 18, 419-438.

MURPHY, S., \& SMITH, M.A. (1991). Writing portfolios: A bridge

from teaching to assessment. Markham, ON: Pippin.

MYERS, J. (1992). The social contexts of school and personal litera-

cy. Reading Research Quarterly, 27, 296-333.

NEW LONDON GROUP. (1996). A pedagogy of multiliteracies: Designing social futures. Harvard Educational Review, 66, 60-92.

OATES, S.F. (1996, December). Literacy as an everyday practice: Meanings and uses high school students make of reading and writing. Paper presented at the annual meeting of the National Reading Conference, Charleston, SC.

OBIDAH, J. (in press). BLACK-MYSTORY: Literacy currency in everyday schooling. In D.E. Alvermann, K.A. Hinchman, D.W. Moore, S. Phelps, \& D. Waff (Eds.), Reconceptualizing literacies in adolescents' lives. New York: Erlbaum.

O'BRIEN, D. (in press). Multiple literacies in a high school program for "at risk" adolescents. In D.E. Alvermann, K.A. Hinchman, D.W. Moore, S. Phelps, \& D. Waff (Eds.), Reconceptualizing literacies in adolescents' lives. New York: Erlbaum.

O'BRIEN, D., STEWART, R., \& MOJE, E.B. (1995). Why content literacy is difficult to infuse into the secondary curriculum: Strategies, goals, and classroom realities. Reading Research Quarterly, 30, $442-463$

OLDFATHER, P. (1995). Songs "come" back to most of them: Students' experiences as researchers. Theory into Practice, 34,

131-137.

ORNER, M. (1992). Interrupting the calls for student voice in "liberatory" education: A feminist poststructural perspective. In C. Luke \& J. Gore (Eds.), Feminisms and critical pedagogy (pp. 74-89). New York: Routledge.

OYLER, C. (1996). Making room for students: Sharing teacher authority in Room 104. New York: Teachers College Press.

PARIS, S.G., WASIK, E.A., \& TURNER, J.C. (1991). The development of strategic readers. In R. Barr, M.L. Kamil, P.B. Mosenthal, \& P.D. Pearson (Eds.), Handbook of reading research (vol. 2, pp. 609-640). White Plains, NY: Longman.

PEARSON, P.D., \& JOHNSON, D. (1978). Teaching reading comprehension. New York: Holt, Rinehart \& Winston.

PHILLIPS, S. (1972). Participant structures and communicative com- petence: Warm Springs children in community and classroom. In C.B. Cazden, V.P. John, \& D. Hymes (Eds.), Functions of language in the classroom (pp. 370-394). New York: Teachers College Press.

PRENTISS, T. (in press). Teachers and students mutually influencing each others' literacy practices: A focus on the students' role. In D.E. Alvermann, K.A. Hinchman, D.W. Moore, S. Phelps, \& D. Waff (Eds.), Reconceptualizing literacies in adolescents' lives. New York: Erlbaum.

PRESSLEY, M., HARRIS, K.R., \& MARKS, M.B. (1992). But good strategy instructors are constructivists. Educational Psychology Review, 4, 3-31.

READENCE, J.E., BEAN, T., \& BALDWIN, R.S. (1981). Content area reading: An integrated approach. Dubuque, IA: Kendall/Hunt.

READENCE, J.E., KILE, R.S., \& MALLETTE, M.H. (in press). Secondary teachers' beliefs about literacy: Emerging voices. In D.E. Alvermann, K.A. Hinchman, D.W. Moore, S. Phelps, \& D. Waff (Eds.), Reconceptualizing literacies in adolescents' lives. New York: Erlbaum.

RUMELHART, D.E. (1980). Schemata: The building blocks of cognition. In R. Spiro, B. Bruce, \& W. Brewer (Eds.). Theoretical issues in reading comprehension (pp. 33-58). New York: Erlbaum.

RUTHERFORD, F.J., \& AHLGREN, A. (1990). Science for all Americans. New York: Oxford University Press.

SANTA BARBARA DISCOURSE GROUP. (1994). Constructing literacy in classrooms: Literate action as social accomplishment. In R.B. Ruddell, M.R. Ruddell, \& H. Singer (Eds.), Theoretical models and processes of reading (4th ed., pp. 124-154). Newark, DE: International Reading Association.

SHOR, I. (1980). Critical teaching and everyday life. Boston: South End Press.

SIEGEL, M. (1995). More than words: The generative power of transmediation for learning. Canadian Journal of Education, 20, 455-475.

STEWART, R.A. (1989). A microethnography of a secondary earth science classroom: A focus upon textbooks and reading (Doctoral dissertation, Purdue University, 1989). Dissertation Abstracts International, 50, 3540A. (University Microfilms No. DA9003468)

STREET, B.V. (1994). Cross cultural perspectives on literacy. In J. Maybin (Ed.), Language and literacy in social practice (pp. 139-150). Clevedon, England: Open University.

STURTEVANT, E.G. (1996). Lifetime influences on the literacy-related instructional beliefs of experienced high school history teachers: Two comparative case studies. Journal of Literacy Research, 28, 227-257.

TAYLOR, D., \& DORSEY-GAINES, C. (1988). Growing up literate: Learning from inner-city families. Portsmouth, NH: Heinemann.

THARPE, R.G., \& GALLIMORE, R. (1988). Rousing minds to life:

Teaching, learning, and schooling in social context. New York: Cambridge University Press.

USHER, R., \& EDWARDS, R. (1994). Postmodernism and education. London: Routledge.

VACCA, R.T., \& VACCA, J.L. (1984). Content area reading. New York: Little Brown.

VOLOSINOV, V.N. (1973). Marxism and the philosophy of language. Cambridge, MA: Harvard University Press.

VYGOTSKY, L.S. (1978). Mind in society: The development of higher psychological processes. Cambridge, MA: Harvard University Press.

WILLIS, A.I. (1995). Reading the world of school literacy: Contextualizing the experience of a young African American male. Harvard Educational Review, 65, 30-49.

ZEBROSKI, J. (1990). Rewriting composition as a postmodern discipline: Transforming the research/teaching dichotomy. In K. Ronald \& H. Roskelly (Eds.), Farther along: Transforming dichotomies in rhetoric and composition (pp. 168-182). Portsmouth, NH: Heinemann.

Received January 3, 1997 Final revision received January 24, 1997 Accepted February 3, 1997 